\title{
Balkanologie
}

Balkanologie Revue d'études pluridisciplinaires

Vol. III, n² | 1999

Volume III Numéro 2

\section{Changes of Emphases : Greek Christendom, Westernization, South-Eastern Europe, and Neo- Mitteleuropa}

Andrei Pippidi

\section{CpenEdition}

Journals

Édition électronique

URL : http://journals.openedition.org/balkanologie/747

DOI : 10.4000/balkanologie.747

ISSN : 1965-0582

Éditeur

Association française d'études sur les Balkans (Afebalk)

Édition imprimée

Date de publication : 1 décembre 1999

ISSN : 1279-7952

Référence électronique

Andrei Pippidi, «Changes of Emphases : Greek Christendom, Westernization, South-Eastern Europe and Neo-Mitteleuropa », Balkanologie [En ligne], Vol. III, n² | 1999, mis en ligne le 22 juin 2010, consulté le 17 décembre 2020. URL : http://journals.openedition.org/balkanologie/747 ; DOI : https://doi.org/ 10.4000/balkanologie.747

Ce document a été généré automatiquement le 17 décembre 2020.

(C) Tous droits réservés 


\title{
Changes of Emphases : Greek Christendom, Westernization, South-Eastern Europe, and Neo- Mitteleuropa
}

\author{
Andrei Pippidi
}

1 «The composition of a provincial history is only a legitimate undertaking if the province in question has formed down the ages a coherent social entity, distinct from and even hostile to its neighbours, enclosed within more or less stable frontiers, and conscious in some fashion of its unity. $»^{1}$ In these words, Marc Bloch intended to delineate the matter on which he focused his research. Accordingly, we are going to see if we can agree on considering the Balkans a province of Europe.

2 Seeing, as I do now, the title I announced for this conclave of scholars dealing with the Balkan area, I am shocked at my own temerity. Particularly so in that I appear to be bringing owls to the goddess Athena, or, as we say in Romania, coxcombs to the gardener. My hope is to show how some stages in the historical development of this region coincide with definitions, old and new, of South-Eastern Europe. One can choose to emphasize the existing contrasts in the region, or one can allow them only secondary importance and retain instead the homogeneity of mores and institutions.

\section{The Balkan disunity vs. the homo-balkanicus}

3 The former viewpoint is well illustrated by some remarks made on the subject, 60 years ago, by a one-time expert on Central and Eastern Europe whose studies can still be found in the bibliography of U.S. foreign relations, Joseph S. Roucek ${ }^{2}$. In 1939, when he explained that the foreseeable satellization of Balkan countries by Hitler's Germany was driven by the ebb of democracy in their internal organization, Roucek signalled also that «the grouping of Albania, Bulgaria, Greece, Roumania and Yugoslavia under the common term Balkan is in a sense artificial, because the five states do not form a 
cultural or an economic unit». And he added: "up to our day, the Balkans have remained a striking example of disunity - geographic, ethnical, linguistic, religious, cultural and political $»^{3}$.

Another professor at Columbia, but one of the previous generation, William M. Sloane, admitted that «the Balkan Peninsula" was a «loose» designation, but found it « historically very useful $»^{4}$. Two themes which were later to influence Roucek's vision might already be discerned in these reflections dating back to 1914. On the eve of another world war, sloane noted the social and political backwardness of the region, which he attributed to the "the early patriarchal state", and, when describing Bucharest as a city of strong contrasts - an image which we can still recognize - Sloane concluded that it was "a microcosm of the country as a whole; at first sight unorganized, disconnected, a mechanical mixture of unrelated parts ». Ab uno disce omnes : Bucharest being taken as a paradigm of Romania, that country offered likewise a model for the totalizing treatment of the Balkans.

The rigid framework of such clichés continues to impede the efforts of modern explorers to understand the Balkan reality. Nevertheless, assessments like those of the above-mentioned American academic travellers were right to note a retarded rhythm of development. Had they crossed Europe one century earlier, they would have found the same variety of states, languages and confessions of faith everywhere going east from France : the Kleinstaaterei was still flourishing in Germany and Italy till 1848 or even until the " 60 s and ' 70 s of the $19^{\text {th }}$ century. Looking at the complex tapestry of the Balkan region, Roucek was impressed by "scores of tongues, dialects and religions", while Sloane felt like being a visitor in an « ethnological museum ». Actually, the map of language areas from Hungary's Eastern border to Istanbul does not show more than nine languages (15 dialects). The religious distribution includes ten traditional confessions of faith, representing the three main religions ${ }^{5}$. We could compare this not only with the unprecedented and still-growing number of Churches and sects in the U.S. today, but also with the historical situation in Central Europe, where both before and after the Reformation the tendency for religious identity to be added to ethnic difference was by no means unknown. So, after all, what was perceived by foreigners as a patchwork, in political and ethnic terms, was the exaggerated reflex of a situation that could have been met more westwards at an earlier stage. The judgement passed by such descriptions of the Balkan peninsula might also be influenced by two other factors : the migrations called by Cvijić « metanastatic movements » - which, in many cases, were mass deportations ordered by the Ottoman administration, or some exodus of a fugitive population (Bežanija, bejenie) - and the pattern set by nationalistic-minded scholars who, in every Balkan country, tried to present their own civilisation as the oldest, downgrading the others. Last but not least, our libraries contain quite a few pamphlets under frightening titles, like Atrocités bulgares en Macédoine, Atrocités grecques en Macédoine, Bulgarian Atrocities, or The Balkan Massacres: A Turkish Appeal ${ }^{6}$. That stream of horror journalism was produced by the wars which, in 1912-1913, led to certain adjustments being made to the borders of the first succession states detached from the Ottoman Empire. But in our own day we are witnesses of a second, no less violent, succession crisis, and as a result the stereotype of Balkan multiplicity tends to be reiterated or confirmed.

6 However, like in the old Greek myth, variance of form does not necessarily mean every time a new content. Maybe, we should listen more carefully to the opposite version, in 
favour of the unitary perspective. The Balkans are what they are because, during their long and dramatic history, they were a dead end for successive invasions which left alluvial strata by mixing with the surviving native population. The same thing happened in the two other European peninsulas : for the most Western of them, the last invaders were the Arabs; Italy, after centuries of servitude and many barbarian assaults, was thoroughly swept by the Spaniards (the Austrian rule, the last to be established, should properly by considered a military occupation). In South-Eastern Europe, the retreat of the Turks did not mean a major demographic change before the $19^{\text {th }}$ and $20^{\text {th }}$ centuries, of the peoples who had preceded them, the Slavs and the Bulgars, the Hungarians and the Germans (Saxons), as well as the Gypsies ${ }^{7}$, settled down and in the meantime the large Romanized core of the Balkan population was constantly diminished, being assimilated. Archaeologists and ethnographers refer to a folk culture, presumably of neolithic origin, and they draw our attention, rightly or wrongly, to the ancient Thracians and Illyrians, mythic ancestors of the Balkan races. An exhibition at the Boston Museum of Fine Arts, showing the results of archaeological excavation in Bulgaria, presented recently several beautiful examples of gold jewellery of the $5^{\text {th }}$ century B.C. , an art of which analogous vestiges could easily have been found on the Northern bank of the Danube.

7 The claims of ethnologists and especially those of anthropogeographers - of a school once brilliantly represented by Cvijić and Ancel $^{8}$ - are less convincing. From the study of economic and technological data, of traditional dress and popular beliefs, of space perception and distribution, or of kinship relations, some specialists have asserted the existence of a homo balcanicus. What is questionable in this perhaps too sanguine opinion is the interpretation of a complex set of circumstances as relevant for, or unique to, our particular civilization area, though similar situations may be discovered in completely different societies that find themselves in the same stage of development. For instance, the fictitious genealogies which accounted for the land distribution in the traditional village community of Wallachia and Moldavia have been identified by the anthropologist Jack Goody during his fieldwork in Ghana'.

On the other hand, the view, largely shared in the West, about the Balkan wars, including the recent conflicts in Croatia and Bosnia, has been that they were an outbreak of ancient and violent hatreds among the local populations, but this line of interpretation is essentially false ${ }^{10}$. For most of their history, the Slavic peoples of the region have lived mixed together, without a clear-cut division, for instance, between Bulgarians and Serbs. The absence of an ethnic identification was still evident in 1848 from the answer given by the peasants of Himara (a zone presently mapped on the Albanian coast), when Edward Lear asked them what they were : "Christians" was their first reply, then "Himariots" (the actual designation, according to our knowledge, would probably have been Vlachs) ${ }^{11}$. The religious specificity was the only one deeply ingrained, as it had been accepted and encouraged by the Turks, who invented the collective identity system of the "millet", a community based on shared adherence to a non-Moslem faith. During the Ottoman period, terms like "Bulgarian" or "Greek" were not used to refer to ethnic or national groups : they designated sociocultural categories, or, if you wish, estates, mostly associated with one language : "Greek" for a merchant, "Vlach" for a shepherd and "Bulgarian" for a farmer or market gardener ${ }^{12}$. When the language distinction was not considerable, the differentiation was imposed from above either by the political authority, or by the spread of literacy, which was instrumental in developing the sense of national identity. Literacy was not something innocent, 
acquired for pure pleasure, but was part of the drill imparted by the modern liberal state.

Thus, even in this representation of the Balkans as a historical and cultural unit, we find two lines of argument : one, which gives it the dimensions of a primordial fact, and the second, which concludes that this unity is the product of special geopolitical conditions (above all, the successive foreign rules: first, that of the Roman Empire, then of the Byzantine state, followed by the "Tourkokratia"). This last interpretation, pointing out the remnant conditions which have brought coherence to the region, has a further variant, overcharged with emotionalism, which emphasizes the role of the Orthodox Church as having protected the Christian people under Turkish domination from any alien influence. However, this assumption fails to explain why the Bulgarians and Serbs were capable of mutual ferocity, no less than were the Serbs and Croats when they were fighting each other without having in common the same religious creed.

Huntington's notorious theory has, on the contrary, turned the division between Catholic and Orthodox into a major and general conflict, one for which it is impossible to achieve concilation. But not only does the association of Orthodox and Moslem contradict both the logic of the demonstration and the historical tradition; what is more questionable in this new partition of Europe is the integration of the Baltic countries into the Western pattern. They are obviously Northern, neither Western, nor Eastern, and only their annexation by Russia made them a part of Eastern Europe since the $18^{\text {th }}$ century; otherwise, they would have claimed their independence from Sweden, and would have got it more easily. Another strong objection is that the borderline between the Habsburg and the Ottoman Empires did not acquire its importance because of its religious function, but as a result of the imperial policies aimed at building up military bulwarks, and more especially as a consequence of different rates of cultural evolution. The fierce opposition of the Orthodox clergy to Catholicism should not be treated as a fatal hostility, of the "cats and dogs" type. Catholicism being hierarchic and heavily disciplinarian, the village priests, who were elected by their flock, struggled for their autonomy, as did the monastic houses : it was therefore a rural solidarity movement from below which cemented Orthodox conservatism.

11 Two more recent interventions in the debate deserve particular attention. For Larry Wolff, "Eastern Europe" is an invention of the Western Enlightenment. The separation of Europe into spheres of domination in 1944-1945 was possible, because Eastern Europe « had long ago been imagined, discovered, claimed and set apart $»^{13}$. The is true, of course; however, the peculiarities of the Eastern pattern of development had already existed for at least three centuries before the Enlightenment (tales about the cruelty of barbarous rulers like Vlad the Impaler, or Ivan the Terrible, had propagated a repellent image of the Eastern society only because the Western mind was already prepared to accept it ${ }^{14}$. At a time when historians indulge themselves in anatomies of "inventions" and "imagined communities", another attack upon the present identification of the Balkans has come from Maria Todorova. She is ready to admit the objective existence of this geographic/cultural unit, but, her critique being directed against the prejudiced Western image, this is indeed a passionate plea for the European integration of this region. In the Balkan identity as seen by Todorova, the decisive component is the Ottoman legacy. As such, her last word is to doubt that this originality will last ${ }^{15}$. 
12 This brings us again to the variations undergone by the name of the region through the medieval and modern centuries, keeping in mind that each one referred to a different historical reality. As long as the basileia ton Rhomaion was alive, nobody, either inside, or outside its frontiers, thought to separate the Balkan peninsula from the Empire. The rise of the Bulgarian and Serbian states did not have the significance of a secession : they were simply competitors to the Byzantine Empire. Samuel or Dušan could never have been what the nationalist mythology has made of them. As Robert Lee Wolff was right to argue : «to peoples starved of history, suddenly conscious of national identity, trying to acquire heroic traditions, the deeds of princes long since dead assumed enormous importance $»^{16}$. If ever conceived as a whole, the territory between Constantinople and the Danube was identified with the core of the Empire, the Romania, a space which the Turks called Roumeli, while medieval Western travelers knew it as Romanie. The same expression is familiar to the reader of Italian sources, where it meant the maritime possessions of Venice or even, in a broad sense, the Aegean basin, surrounded by the shores of Asia Minor, Thrace, continental Greece and the Peloponnese. Though it is not attested in contemporary texts, the most convenient designation for the Balkan Peninsula from the $13^{\text {th }}$ to the $15^{\text {th }}$ century seems to be "Greek Christendom". "Slavia Orthodoxa" would suggest more about the ethnic character of the majority of the non-Moslems and about the language of the manuscripts which survived in monastic libraries. These were, however, translations, for the most part, and their original language was, unmistakably, Greek. There was not a severance of contacts with the outside world, but in the relation with the West, whether confrontational or collaborative, the nature of this society was perceived as alien and usually associated with the Eastern Church, a generalization which caused a lasting distrust. Meanwhile, the internal situation in this phase was characterized by an inexorable drive towards fragmentation. Less so in the Romanian principalities, where, nevertheless, vague, indeed unformulated, rules of succession to the throne, coupled with the instability of borders, lay behind most of the military adventures throughout the $14^{\text {th }}$ and $15^{\text {th }}$ centuries. It was the proximity of the two, relatively more consolidated, kingdoms of Hungary and Poland which precipitated the concentration of power in Wallachia and Moldavia. An important observation which must be added is that the blatant assertion of Christianity did not preclude the survival of heresy and pagan beliefs (the number of extant charms, spells, incantations, and magical prayers is surprisingly large, most of such texts being of quite recent date). This religious confusion is almost general in the Balkans and bears the stamp of the complex, archaic, Byzantine tradition ${ }^{17}$.

\section{About the area's originality}

Our periodization cannot avoid the phase of Ottoman domination, with the historical legacy it has left. Its main consequence is that Islam is there to stay, which does not mean only the existence of scattered minorities (in Greece, Albania, Macedonia, Bulgaria, Serbia and Romania), but also to stay in the shape of the newly built state of Bosnia - a project which does not seem more "unreasonable" than Bernard Newman's idea, at the end of the Second World War, to create a Jewish state in Bessarabia. Up until the turn of the $19^{\text {th }}$ century, the presence of the Ottoman Empire achieved in our region a single, independent and virtually closed system. It is also the only epoch 
during which the name of Balkan might have been appropriately applied. The interests which the economic and political network between Constantinople and Hotin was intended to serve were those of the Turkish military machinery. Without any exaggeration, we can say that the prolonged wars - either against the sultan's enemies, or fought inside the system - were the crucible in which ethnic consciousness reached crystallization. This process progressed from the periphery to the centre. The first territorial communities which acquired a sense of their historic identity were the Romanian principalities and then Serbia. Greece was not a borderland, but the first Greek subversive actions, though inspired by and from centres of Hellenism which were in a peripheral position, did not aspire to a local independence : they envisaged the future organization of a space no less multinational than the Byzantine Empire had been. Rhigas stressed the unity of those speaking Greek - who was not then fluent in that language, among the cultural, ecclesiastical and economic élites of the Balkans? Whereas the Great Church of Constantinople emphasized the unity of all orthodox Christians, irrespective of their mother tongue, the only criterion for differentiation to be acknowledged by the Turkish bureaucracy was that of status in the hierarchy of the Ottoman state. Consciously or not, the Turks played one ethnic group against the other, encouraging some divisions and conflicts which we now accept too easily as spontaneous. Even when they did suppress internal strife or forced it into compromise, they did so in order to maintain the military order and the state organization. I wonder whether we should include the Ottoman period in this sequence of historical conditions which changed something in the definition of the region. Oddly enough, it would seem that only when it became a thing of the past, did it lend its symbolic weight to our perception of the region.

It was only Westernization which gave rise, together with national consciousness, to a general sense of the region's originality, lost until then in the network of bonds with the imperial capital. Every nation started to idealize its own past, as a compensation for present frustration or as a promise of a great future. When the new states endeavoured to construct their own administrations, they tended to acquire privileged bureaucracies which inherited from the Ottoman one strategies to eschew responsibility and to form protégé networks. Later, every political party would develop its own clientèle system on this model. Lacking cities of the Western medieval type, these countries maintained a relationship between city and rural environment from which all the benefit was drawn by the urban consumers. The orientalization of the Balkans under Ottoman rule had reinforced the old reaction of seeing there a medley of peoples "half Christian half Turkish"18. A long range of projects which prepared the partition of the Ottoman Empire - or, at least, its mutilation - identified "Turkey in Europe" as a space to be colonized and annexed by the Western powers ${ }^{19}$ : a way, they already argued, to return to Europe. Whenever travellers from the "enlightened" West ventured to cross the Balkans, they discovered what they expected to find: that is, a striking contrast with their own society. The state of things they witnessed differed from the more familiar landscape of England or France in two essential respects : the backwardness of economy and that lack of liberty which came to be called "despotism" of Greek and Roman ruins, and another contrast, that of a venerable past with the humble present, was no less typical for this kind of literature. 
15 Although the first description of the region under the name of Balkanhalbinsel, or in more classical terms, Haemushalbinsel, dates from 1808, these designations at first had a merely geographic meaning. Was it not Metternich who, at the same time, contested that Italy might be more than a geographic expression? It is surely significant that, in the Balkans and in the Romanian lands, when somebody travelled westwards, he was said to be going "inside". The West was identified with the core, by the inhabitants of the outposts : the position being essential in this system of values, it was already a form of idealizing Western Europe ${ }^{21}$. As a result of their own experience, if they had the opportunity to visit it, those who ascribed positive qualities to the West came to be conscious of the gap existing between their own world and the superior civilization of the Enlightenment. The same providers of knowledge were, in their own countries, the most influential propagators of modernization. They would not have thought of the Balkans as a unitary structure, nor would they have expected the necessary reforms to be directed by the Ottoman officialdom. Once they had conceived the mould of the nation-state, innovation could come only through a bilateral contract between the nation and that West which they represented as the sole custodian of all sciences and skills. Therefore the idea of a confederation established around a Balkan or a Danubian nucleus was suggested only by observers from outside, who dreamt of a solution to appease ethnic antagonism. Their expectations could not be fulfilled, even in a lesser form - King Charles I of Romania was to refuse the crown of Bulgaria in $1887^{22}$ - and the dismantling of the Ottoman Empire continued.

When the name of "South-Eastern Europe" was found, it was once again a German geograher, Theobald Fischer, who was responsible for its theoretical elaboration and popularization. The date was 1893 , only a few years before that other catchword, "Mitteleuropa", became fashionable. The new concept expressed the striving towards a larger unity, as it included Romania, at least the old Kingdom. Two political connotations can be grasped in the history of this notion of "Südost". One is revealed by the goals of Habsburg politics around 1908, at the time when the annexation of Bosnia-Hercegovina marked a short-lived victory of the Triple Alliance in the Balkans. The truth is that the 1876 intervention of Austrian troops, which had opened the way for the latter move, had been justified by the need to use force to impose a negotiated settlement after a brutal outbreak of Moslem intolerance ${ }^{23}$. In the present circumstances, we can not blame this attitude. The interest of Austrian and German scholars in the Balkans (Nopcsa, Weigand, Jireček, Patsch, etc.) was increasing by the turn of the century and in 1911 a first centre for the study of South-Eastern Europe emerged at the University of Vienna ${ }^{24}$. It aimed to introduce the Balkan nations and the intricate historic connections among them to diplomats who wrestled unsuccessfully with such problems. Their failure to assess events correctly was quick to show and the war brought this activity to a premature end. The second time around, Südosteuropa did not have any more luck. This was in the Thirties, in an atmosphere charged with ideological passion. The political stimulus to consider this "Raum" as naturally complementary to the "Reich" became more pointed, and Nazi propaganda had begun to exert a perceptible, though veiled, influence within the structure of academic life in the Balkan countries as well as in Romania and Hungary ${ }^{25}$. In the prospect of that united Europe which was offered by Hitler's ambition, Südosteuropa found a justification. And soon, one after another, the countries of the region concluded alliances with the Axis or were occupied. Hence in the late " 40 s and early '50s this compromised term was difficult to accept, also because the Soviet occupation and 
Communization had again divided the region in two camps, as it had been during the revisionist campaigns, but on a different separation line.

17 A remarkable effort to introduce the name of South-Eastern Europe, with the advantage of including Romania, was made in Bucharest following the end of the Balkan wars in 1913. It was not only a plea for the peaceful solution of international disagreements and for the reciprocation of more understanding in the relations among the irascible Balkan nations. What the Romanian historian Nicolae Iorga intended to do was to assert the cultural unity of the Peninsula and to assure for his own country, by a rational approach, the allies she needed when, from both sides, Russia and AustriaHungary, she had experienced the arrogance of imperialist politics. This independent initiative won some support in Romania from the intelligentsia, Iorga being assisted by two younger colleagues, the archaeologist V. Pârvan and the geographer and geologist G. M. Murgoci. The creation of an Institute "pour l'étude de l'Europe sud-orientale" in 1914 contributed substantially to the development of this interest, especially through the publication of a "Bulletin", to become, ten years later, the Revue historique du Sud-Est européen ${ }^{26}$. Before Budimir and Skok issued in Belgrade their Revue internationale d'études balkaniques, the Romanian journal was the only one in the field, though gradually, reflecting the tireless activity of Iorga, who was himself writing most of the articles and all the reviews, it adopted a broader scope, so that it covered the medieval and modern history of Western Europe as well. As early as 1914, Iorga had published a history of the Balkan states (in Romanian, of which there is also a French translation) ${ }^{27}$. Author of a classic work on the Ottoman Empire ${ }^{28}$, he was now giving it a counterpart: after a survey of the life of the subject peoples, most of the book described the contacts with Russians and Austrians, the national awakening and the achievement of independence. Although the Romanians, clinging to their distinctive Romance language, used to reject any suggestion that they were a Balkan people, Iorga, whose political doctrine is often classified as being chauvinist, emphasized their close relations with the South Danubian territories, their religious allegiance to the oecumenical Patriarchate, the protection they granted to the Balkan culture and later to the Balkan revolutionary emigration. The question was again discussed in two later works, Le caractère commun des institutions du Sud-est de l'Europe (1929), where Iorga's scholarship was drawn to the historical sociology of the peasantry, and Byzance après Byzance (1935), which studied the survival of Byzantine tradition in several autonomous enclaves.

To analyze in the light of modern theories and methods what historic experience the Romanians share with their neighbours of the Balkan Peninsula has been the concern of the scholars who are working in the Bucharest Institute since 1963, when it was revived after a 15 years' eclipse. When the late Nicolae Ceaussescu, in search of an independent version of Communism which would make his regime popular, started talking about positive historical associations with the other South-East European nations, it was a way of idealizing the attempts to defend Romanian freedom against Russian, Turkish and Habsburg encroachments. This led gradually to an extreme nationalist discourse which implied isolationism, thus contradicting the very purpose for which these regional studies had been encouraged. Since 1990, a dialogue is freely engaged between those who adopt, more or less openly, the same autistic view of Romania's history and the rival conception which would enlarge the notion of Romania, regarding this country as part of one context, or another ${ }^{29}$. 


\section{Definitions' and borders' changes}

19 The trouble is that, as always, the course of ideas is determined less by their own dynamic force than by external pressure. We are watching a new shift of emphasis. As an alternative both to "South-Eastern Europe" (too close to a grim image of the Balkans), and to the Soviet-dominated "Eastern Europe", "Central Europe" is proving a more fashionable definition, which already has the blessing of the U.S. State Department. I learnt from one of President Iliescu's speeches that Romania is in Central Europe. Every time I have been talking with somebody holding office in the Romanian government or diplomatic service, I was given the same disappointing answer : « we are not concerned about South-Eastern Europe, we are in Central Europe, you know ».

No, I wasn't aware. There is one feature of this situation which worries me. The term "Central Europe" was not resuscitated (by Milan Kundera in 1984) for the purpose of extending South-Eastern Europe to the West, but for that of distinguishing what was then Czechoslovakia, Poland, and Hungary from the Eastern bloc and from the Balkans. The Višegrad treaty, signed in an apt location near the picturesque ruins of a castle that had been already, in the $14^{\text {th }}$ century a meeting place for the three kings, and the recent welcoming to NATO of the same three states (no mistake: Slovakia was a province of medieval Hungary) successfully demontrated to us that Central Europe has this political significance. When Naumann, in 1915, launched the idea of a space, placed between the two empires then at war, Germany and Russia, which he considered adequate for German and Austrian economic and cultural hegemony, it did not include Romania, Bulgaria, Serbia and Greece. They are still left out in the shadows of the Balkan mountains. The only exception is Greece, whose membership in both NATO and the EU is equivalent to being an honorary Central European. But, then, one has the right to ask : what is left of South-Eastern Europe ? ${ }^{30}$

One of the lessons of this argument is that not only the definitions change : the borders also are liable to move. I could tell you the story of a friend of mine who was born in Soviet Bessarabia at the end of 1940, lived for the first three years of her life in Romania (without moving from her mostly Albanian village) and then, because her parents fled west in front of the Red Army, found herself in Romania - same name, but another country, - while the village fell within Ukraine. But this is another story. A more challenging question is how a country may change location. If South-Eastern Europe did not exist before the continent qualified as a historical unit, the principalities of Wallachia and Moldavia, though they belonged to the Ottoman Empire, were not a part of the Balkans. Their unification, which was one of the results of the Crimean War, marked the day when a new nation was born. However, no sooner had the confiscation of monastic properties been promulgated in 1863, in imitation of a similar reform enacted in Greece, 30 years before, than the country began to leave South-Eastern Europe. The quarrel with the Constantinople Patriarchate and the decision to use in church only the Romanian language were omens of a new orientation, which was confirmed by the declaration of independence in 1877. Of the provinces acquired in 1918, Transylvania and Bukovina had a strong Central European character, owing to the centuries of Habsburg administration. From then on until 1940, the tradition which prevailed was the South-East European one. Not only the loss of Northern Bukovina, not only the mass emigration of the Transylvanian Saxons, but the social ascension of a rural population whose values were decidedly of Balkan origin 
have been, during the Communist regime, factors which accentuated the development of this tradition. There is, nevertheless, the question of the future path to be taken by Romania. The contacts, suddenly revived with Turkey and Greece, and, quite recently, the sympathy shown by the Romanian press for Serbia's plight, are valid reasons to think that Romania's aspiration to join Western Europe will coexist many years ahead with those elements of her historic inheritance - Byzantine, Ottoman, $19^{\text {th }}$-century liberal and populist - which attach her to South-Eastern Europe.

\section{NOTES}

1. Bloch (Marc), The Ile-de-France. The Country Around Paris, Ithaca, NY : Cornell University Press, 1971, p. 120.

2. He was already the author of a paper on the educational experiment at Vălenii-de-Munte in Romania, published in School and Society, 14, 1931, pp. 199-200. The last of more than 60 items bearing his signature is The United States and the Persian Gulf. 1985.

3. Roucek (Joseph S.), The Politics of the Balkans, New York / London, 1939, p. 1.

4. Sloane (William M.), The Balkans, a Laboratory of History, New York, 1914, pp. 3, 83, 125.

5. See Stoianovich (Traian), A Study in Balkan Civilization, New York, 1967, figures 3a and 3b, which omits three minorities : the Armenians of the Gregorian creed; the Uniates; and the (mostly Hungarian) Uniates. "Traditional" here means older than the $18^{\text {th }}$ century.

6. All these brochures are cited by Seton-Watson (R. W.), The Rise of Nationality in the Balkans, New York, 1918.

7. It is difficult to assign a date to the first Armenian settlements, but, most likely, they were already present in the Byzantine Empire, in mediaeval Bulgaria and in the Romanian Principalities. The arrival of the Roma, who spread all over the region as blacksmiths and who, in the Romanian lands, were reduced to slavery, can safely be attributed to the $13^{\text {th }}$ century.

8. Cvijić (Jovan), La Peninsule Balkanique. Géographie humaine, Paris, 1918; Ancel (Jacques), Peuples et nations des Balkans, Paris, 1926.

9. Burke (Peter), « History as Social Memory », in Butler (Thomas), ed., Memory. History, Culture and the Mind, Oxford, 1989.

10. The demonstration of Malcolm (Noel), Kosovo: A Short History, New York, 1999, pp. xxvii$\mathrm{xxix}$, is very welcome.

11. Lear (Edward), Journals : A Selection, London : ed. Herbert Van Thal, 1952.

12. See the excellent observations of Danforth (Loring M.), The Macedonian Conflict. Ethnic Nationalism in a Transnational World, Princeton, 1996, pp. 57-65.

13. Wolff (Larry), Inventing Eastern Europe. The Map of Civilization in the Mind of the Enlightenment, Stanford, CA, 1994, pp. 34, 7, 143.

14. See the stimulating contribution of Schöpflin (George), " The Political Traditions of Eastern Europe », in Graubard (Stephen R.), ed., Eastern Europe - Central Europe - Europe, Boulder, CO, 1991.

15. Todorova (Maria), Imagining the Balkans, New York / Oxford, 1997, pp. 12-13.

16. Wolff (Robert Lee), The Balkans in Our Time, New York, 1967, p. 55. Much earlier the same observation was made by Brailsford (H. N.), Macedonia. Its Races and their Future, London, 1906. 
17. Maguire (Henry), ed., Byzantine Magic, Dumbarton Oaks, MD, 1995. For a comprehensive general account see Mathiesen (Robert), " Magic in Slavia Orthodoxa, the Written Tradition », in ibid.

18. Wolff (Robert Lee), Inventing Eastern Europe (op.cit.), pp. 22, 177, 288, 291, 293, illustrates to what extent the Western travellers were inclined to use expression like "mélange" or "miscuglio" of races and tongues when speaking about the population of Russia and Turkey.

19. There is still some profit to be had in consulting Djuvara (T. G.), Cent projets de partage de la Turquie, Paris, 1914.

20. See for instance the description of Serbia in 1717 by Wortley Montagu (Lady Mary), Letters from the Levant, During the Embassy to Constantinople, 1716-1718, New York, 1971, p. 101. Cf. Wolff (Robert Lee), Inventing Eastern Europe (op.cit.), pp. 38-43.

21. Todorova (Maria), op.cit., p. 43, cites the British historian William Miller, who, in 1898, remarked that " going to Europe " meant a journey to any of the countries situated west of the the Peninsula, «thereby avowedly considering [the Balkan region] as quite apart from the European system ».

22. Seton-Watson (R. W.), op.cit., pp. 122, 147.

23. Evans (Arthur J.), Through Bosnia and the Herzegovina on Foot, London, 1876 ; Trevor (Roy), My Balkan Tour, London - New York, 1911; Schmitt (Bernadotte E.), The Annexation of Bosnia, 1908-1909, Cambridge, 1937. See now Malcolm (Noel), Bosnia : A Short History, London, 1994.

24. From 1911 to 1914, Th. Schiemann, L.K. Goetz, Otto Hotzsch and H. Übersberger were publishing in the Berlin Zeitschrift für Osteuropäische Geschichte.

25. See for instance the Osteuropäische Jahrbücher, where Georg Stadtmüller was already active. In 1942 it became Süd-Ost Forschungen.

26. Pippidi (Andrei), "Pour l'histoire du premier Institut des études sud-est européennes ", Revue d'études sud-est européennes, 16 (1), 1978.

27. Iorga (Nicolae), Histoire des Etats balcanique, Paris, 1925. Cf. idem., Histoire des Roumains des Balcans, Bucarest, 1919 ; idem., Histoire de l'Albanie, Bucarest, 1919.

28. Iorga (Nicolae), Geschichte des osmanischen Reiches, 5 vols., 1908-1913.

29. Pippidi (Andrei), « Necesitatea unui institut pentru studiul sud-estului european », Buletin (Bucuresti), 5, 1994.

30. See Ash (Timothy Garton), "The Puzzle of Central Europe ", New York Review of Books, 46 (5), $18 / 03 / 99$.

\section{AUTEUR}

\section{ANDREI PIPPIDI}

Andrei Pippidi holds a PhD from Oxford University. He is Professor of Mediaeval Studies at Bucharest University, a senior researcher at the Institute for South-East European Studies (Bucharest) and President of the Romanian Commission for Historic Monuments. Among his numerous publications is Hommes et idées du sud-est européen à l'aube de l'âge moderne (Paris/Bucharest, 1980). 